\title{
Hubungan antara Forgiveness dan Post Traumatic Growth pada Perempuan Korban Kekerasan dalam Pacaran pada Usia Dewasa Awal di Kota Bandung
}

\author{
Annisa Salsabila*, Dinda Dwarawati \\ Prodi Ilmu Psikologi, Fakultas Psikologi, Universitas Islam Bandung, \\ Indonesia. \\ *annisasalsabilan@gmail.com, dindadwarawati@unisba.ac.id
}

\begin{abstract}
Dating violence can traumatize a victim. However, in women who have experienced trauma, there are some women who can bounce back, even change more positively, and experience post-traumatic growth, one of the coping strategies for victims is to forgive. The purpose of this study was to examine the relationship between forgiveness and post-traumatic development in victims of dating violence. This research is a quantitative research with purposive sampling technique. The subjects in the study were women victims of dating violence who lived in Bandung City who experienced trauma, which was seen by measuring PTSD from the victim using a PCL-5 measuring instrument, then the subject was identified post-traumatic growth with a PTGI measuring instrument and then the level of forgiveness was measured using a measuring instrument with a subscale self-forgiveness and forgiveness of others on the TRIMS measuring instrument. The data analysis techniques in this study were data processing, coding, data presentation, and data interpretation. The research subjects were 96 early adult female respondents with categorization of having moderate to high PTSD. The results showed that there was a relationship between forgiveness and post traumatic growth in victims of violence. in courtship of 0.332 which means that there is a fairly close relationship between the two variables.
\end{abstract}

Keywords: Forgiveness, post traumatic growth, dating violence.

\begin{abstract}
Abstrak. Suatu tindak kekerasan dalam pacaran bisa membuat seorang wanita mengalami trauma. Namun pada wanita yang mengalami trauma terdapat wanita yang dapat bangkit kembali, bahkan berubah lebih positif, dan mengalami pertumbuhan pasca trauma, salah satu strategi coping para korban ialah dengan melakukan pemaafan. Tujuan penelitian ini untuk melihat bagaimana hubungan antara pemaafan dan perkembangan pasca trauma pada korban kekerasan dalam pacaran. Penelitian ini merupakan penelitian kuantitatif dengan teknik Purpossive Sampling. Subjek dalam penelitian adalah perempuan korban kekerasan dalam pacaran berdomisili di Kota Bandung yang mengalami trauma yang dilihat dengan mengukur PTSD dari korban menggunakan alat ukur PCL-5 kemudian subjek diidentifikasikan pertumbuhan pasca trauma dengan alat ukut PTGI dan kemudian dilihat tingkat pemaafan dengan menggunakan alat ukur dengan subskala pemaafan diri dan pemaafan orang lain pada alat ukur TRIMS. Teknik analisis data dalam penelitian ini adalah pengolahan data, pengkodean, penyajian data, serta interpretasi data. Subjek penelitian adalah 96 responden wanita dewasa awal dengan kategorisasi memiliki PTSD yang sedang-tinggi. Hasil penelitian menunjukkan terdapat hubungan forgiveness dan post traumatic growth pada korban kekerasan dalam pacaran sebesar 0,332 yang berarti menunjukan adanya hubungan yang cukup erat tantara kedua variable.
\end{abstract}

Kata Kunci: Forgiveness, post traumatic growth, kekerasan dalam pacaran. 


\section{A. Pendahuluan}

Individu yang berusia 18 sampai 25 tahun memasuki tahap perkembangan dewasa awal (Santrock, 2012). Berdasarkan tahap perkembangan menurut Erikson (dalam McLean \& Syed, 2015), masa dewasa awal memasuki tahap yang disebut dengan intimacy vs. isolation. Pada tahap relasi yang intim mulai berlaku dan berkembang karena salah satu tugas perkembangan dewasa awal ialah menjalin relasi yang intim dengan individu lain seperti pacaran atau menikah (Santrock, 2007). Diungkapkan oleh Bird dan Melville (1994) yang menyatakan bahwa pacaran adalah pertemuan antara dua orang yang sama secara khusus diarahkan untuk menjalin komitmen pernikahan. Hubungan pacaran yang mengarah pada pernikahan biasanya terjadi pada individu yang berusia 18-25 tahun atau pada fase dewasa awal.

Individu yang berpacaran dihadapkan pada situasi yang menuntut untuk mampu menyesuaikan diri, tidak hanya terhadap dirinya sendiri, tetapi juga terhadap pasangannya (Ariestina, 2009). Ketika pasangan tidak mampu mengkomunikasikan ketidaksetujuan atau harapan, maka konflik dapat muncul dan menimbulkan tindak kekerasan pada pasangannya (Florsheim, 2003; Rusyidi \& Hidayat, 2020). Kekerasan dalam pacaran didefinisikan oleh Centers for Disease Control (CDC) sebagai jenis kekerasan yang terjadi pada pasangan intim antara dua orang dalam suatu relasi pacarana yang dapat berupa pelecehan fisik, emosional dan seksual.

Berdasarkan Catatan Tahunan Komnas Perempuan (2020), tercatat kasus kekerasan dalam pacaran sebanyak 1.309 kasus atau sebanyak 20\%. Menurut Komisi Nasional Anti Kekerasan terhadap Perempuan, kasus kekerasan dalam pacaran sering terjadi dan lebih dari $70 \%$ korbannya adalah perempuan dan menempati posisi kedua dalam kasus yang paling menonjol dalam ranah personal setelah kasus kekerasan terhadap istri. (Komnas Perempuan, 2020). Berdasarkan keterangan korban, kebanyakan kasus bermula karena pihak laki-laki meminta korban untuk berhubungan seksual yang kemudian berujung pada tindak kekerasan dan penganiayaan karena pihak perempuan menolak. Sedangkan, banyak kasus kekerasan dalam pacaran yang tidak dilaporkan kepada pihak Komnas Perempuan (Herusansono, 2012 dalam Kompas.com).

Sembiring (2018) mengatakan pada hasil penelitiannya jika perempuan cenderung menjadi korban kekerasan dalam pacaran. Hal tersebut dikarenakan adanya ketakutan atau kekhawatiran dari perempuan jika kekasihnya akan membalas dendam atau menyakiti lebih jauh. Sikap yang demikian juga didukung dengan perilaku yang ditunjukkan oleh perempuan seperti pasrah dan menerima, serta mengharapkan bahwa hubungan yang dijalani akan berjalan baik-baik saja dengan harapan akan berubah menjadi tidak ada perilaku kekerasan lebih lanjut. Hal tersebut yang menyebabkan kekerasan dalam pacaran jarang dilaporkan di jalur hukum dan dianggap baik-baik saja.

Bentuk-bentuk kekerasan yang dilakukan oleh pelaku bervariasi, antara lain kekerasan dalam segi emosional, seksual, fisik, hingga terkait dengan ekonomi. Penelitian yang dilakukan oleh Sembiring (2018) mengungkapkan bahwa kekerasan dalam segi emosional adalah hal yang paling sering dijumpai serta interogasi merupakan hal yang paling sering dilakukan sebagai bentuk kekerasan emosional. Hal tersebut dikarenakan anggapan bentuk ekspresi dari tanda sayang dan romantis, sehingga banyak yang menganggap wajar tindakan tersebut. Bentuk kekerasan lain yang dialami oleh responden dalam penelitian Sembiring adalah kekerasan seksual dengan aktivitas ciuman yang tidak diinginkan sebagai bentuk yang paling banyak terjadi. Hal tersebut dikarenakan rasa ingin tahu, kurangnya pengawasan dari orang lain yang lebih memahami, sedikit informasi mengenai kekerasan dalam pacaran, hingga alasan-alasan yang mengatasnamakan cinta dan kasih sayang. Perlakuan yang seperti itu yang dapat menimbulkan trauma pada korban yang dapat berpotensi besar menghancurkan masa depan.

Kekerasan dalam pacaran dapat menimbulkan berbagai dampak negatif pada korban, baik secara fisiologis, emosional, maupun psikologis. Dampak secara fisiologis berupa luka fisik, kesulitan tidur dan makan, kehamilan yang tidak diinginkan, tertular penyakit seksual, dan lain-lain (Rusyidi \& Hidayat, 2020). Selanjutnya, dampak secara emosional berupa perasaan bersalah dan menyalahkan diri sendiri, tertekan, penyangkalan, dan lain-lain. 
Selanjutnya, dampak secara psikologis berupa Posttraumatic Stress Disorder (PTSD), depresi, kecemasan, penurunan self-esteem, simtom obsesif-kompulsif, dan lain-lain (Mason, 2013).

Meskipun menimbulkan banyak dampak negatif, tidak semua individu terus menerus memandang kekerasan dalam pacaran yang dialami sebagai pengalaman negatif. Sebagian individu dapat melewati keadaan krisis tersebut, bahkan mengalami kehidupan yang lebih positif setelahnya (Joseph \& Linley, 2012). Hasil penelitian Mason (2013) menunjukkan bahwa korban kekerasan dalam pacaran mengalami beberapa perubahan positif pasca peristiwa kekerasan dalam pacaran, seperti lebih dekat dengan keluarga, merasa lebih kuat, lebih optimis, lebih menghargai dan mensyukuri apa yang mereka miliki, lebih empati terhadap korban kekerasan dalam pacaran dan orang lain secara umum, dan lain-lain.

Istilah yang digunakan untuk menjelaskan perubahan positif ini disebut, post traumatic growth yang didefinisikan sebagai perubahan positif pada kondisi psikologis individu pasca peristiwa traumatis. (Janoff-Bulman, 1992 dalam Tedeschi \& Calhoun, 2004).Post traumatic growth dapat muncul dalam perilaku penghargaan terhadap hidup serta perubahan prioritas, hubungan dengan orang lain yang lebih intim, individu yang lebih optimis, mengalami kemungkinan baru dalam hidup, dan lebih berpartisipasi pada kegiatan religiusitas serta lebih bersyukur (Ramos \& Leal, 2013).

Salah satu strategi koping yang dapat dilakukan oleh korban kekerasan dalam pacaran yaitu dengan cara memberikan pemaafan (forgiveness) pada pelaku (Asnawati, 2017). Namun, dalam memaafkan pelaku kekerasan juga tidak mudah bagi korban sehingga dibutuhkan waktu untuk dapat memaafkan. McCullough (2003) menjelaskan bahwa pemaafan merupakan suatu perubahan motivasi yang terjadi pada diri individu. Menurut Enright (dalam Worthington, 2005), pemaafan merupakan kompleksitas mengenai integrasi dari kognisi, afeksi dan perilaku. Pemaafan dapat membuat individu lebih menerima apa yang sudah terjadi, membuat diri merasa lebih baik dan menahan diri dari amarah yang berlebih. Penelitian yang dilakukan oleh Worthington, dkk (2005) menunjukkan bahwa sikap ketidak inginan untuk memaafkan akan berdampak buruk pada kesehatan dikarenakan adanya stres dalam diri individu tersebut.

Pada penelitian yang dilakukan Hafnidar, Chang, \& Lin (2012) menunjukkan jika berdasarkan hasil analisis Sobel didapatkan bahwa forgiveness dapat menjadi mediator hubungan antara spiritualitas dan PTG sehingga dalam penelitian ini disimpulkan bahwa forgiveness tidak berhubungan langsung dengan post traumatic growth. Sedangkan dalam penelitian yang dilakukan oleh Gilo, Feigelman \& Belz (2020) didapatkan bahwa forgiveness berkontribusi positif terhadap PTG secara langsung melalui proses interpersonal dan kognitif. Temuan ini menyoroti nilai tindakan yang mempromosikan pengampunan diri, kasih sayang, dan penerimaan dalam intervensi psikologis.

Berdasarkan latar belakang yang telah diuraikan, maka perumusan masalah dalam penelitian ini sebagai berikut:

1. Bagaimana forgiveness pada Perempuan Korban Kekerasan dalam Berpacaran Pada Usia Dewasa Awal di Kota Bandung?

2. Bagaimana post traumatic growth pada Perempuan Korban Kekerasan dalam Berpacaran Pada Usia Dewasa Awal di Kota Bandung?

3. Bagaimana Hubungan antara Forgiveness dan Post traumatic growth pada Perempuan

Korban Kekerasan dalam Berpacaran Pada Usia Dewasa Awal di Kota Bandung?

Selanjutnya, tujuan dalam penelitian ini diuraikan dalam pokok-pokok adalah untuk mendapatkan data secara empiris mengenai Hubungan antara Forgiveness dan Post traumatic growth pada perempuan korban kekerasan dalam berpacaran yang berusia dewasa awal di Kota Bandung.

\section{B. Metodologi Penelitian}

Metode penelitian yang digunakan adalah metode penelitian Kuantitatif Korelasional. Penelitian korelasional kuantitatif merupakan penelitian yang dimaksudkan untuk mengetahui ada tidaknya hubungan antara dua atau beberapa variabel (Arikunto.S., 2005, p. 247). Penelitian ini bertujuan untuk menguji bagaimana korelasi antara forgiveness dan 
Posttraumatic Growth pada orang yang pernah menjadi korban kekerasan dalam pacaran. Variabel dalam penelitian ini meliputi dua variabel yaitu forgiveness (X) dan post traumatic growth (Y).

Alat ukur yang digunakan dalam penelitian ini adalah kuesioner atau angket dengan teknik pengumpulan data yang dilakukan dengan cara memberi seperangkat pernyataan tertulis kepada responden untuk dijawabnya (Sugiyono, 2008). Sejumlah pernyataan tertulis digunakan untuk memperoleh informasi dari responden yang merupakan laporan tentang pribadinya, sikapnya terhadap sesuatu hal yang diketahui. Adapun model angket pada penelitian ini mengacu pada Skala model Likert. Hasan (2002) mengemukakan bahwa Skala Likert untuk mengukur sikap, pendapat, dan persepsi seseorang atau sekelompok orang tentang fenomena sosial.

Dalam penelitian ini telah ditetapkan secara spesifik oleh peneliti, yang selanjutnya disebut variabel penelitian. Penelitian ini menggunakan tiga alat ukur yaitu: PCL-5 (PTSD Checklist for DSM-5), skala TRIMS (Transgression Related Interpersinal Motivations Scale) dan PTGI (Post traumatic growth Inventory). Alat ukur PCL-5 digunakan untuk melihat tingkat trauma pada korban kekerasan dalam pacaran. Alat ukur TRIMS digunakan untuk melihat gambaran pemaafan pada korban kekerasan dalam pacaran. Sedangkan, PTGI digunakan untuk memperoleh gambaran mengenai perubahan positif responden dalam merespon keadaan kekerasan dalam pacaran yang pernah dialaminya.

Dalam penelitian ini populasi yang diambil adalah perempuan berusia 18-25 tahun yang pernah menjadi korban kekerasan dalam pacaran dan berdomisili di Kota Bandung dan sudah mengalami perubahan positif setelah kejadian pasca trauma. Sampel penelitian adalah sebagian dari populasi yang diambil sebagai sumber data dan dapat mewakili seluruh populasi. Sampel dalam penelitian ini adalah perempuan yang pernah menjadi korban kekerasan dalam pacaran dan sudah terlepas dari hubungan tersebut yang kemudian mengalami perubahan positif setelah kejadian traumatis.

Karena populasi tidak diketahui jumlahnya, maka rumus yang dibutuhkan untuk mengetahui jumlah sampel adalah menggunakan rumus Lemeshow (dalam Riduwan \& Akdon, 2010) dan berdasarkan rumus tersebut maka $n$ yang didapatkan adalah $96,04=96$ orang sehingga pada penelitian ini setidaknya penulis harus mengambil data dari sampel sekurangkurangnya sejumlah 96 responden.

Teknik samping yang digunakan dalam penelitian ini adalah Purposive Sampling yang dilakukan dengan cara mengambil subjek bukan didasarkan atas strata, random atau daerah tetapi didasarkan atas adanya tujuan tertentu (Sugiyono, 2019). Adapun untuk kriteria subjek penelitian yang dijadikan sampel dalam penelitian ini sebagai berikut:

1. Berdomisili di Kota Bandung

2. Perempuan dewasa awal berusia $18-25$ tahun

3. Pernah mengalami kekerasan dalam pacaran baik itu secara fisik, psikis maupun seksual

4. Memiliki trauma akibat mengalami kekerasan dalam pacaran

5. Sudah terlepas dari hubungan penuh kekerasan

6. Menunjukkan adanya perubahan yang positif

Analisis data dalam penelitian ini meliputi uji statistik yang dilakukan dengan menggunakan bantuan aplikasi SPSS versi 25. Analisis data digunakan dalam penelitian ini adalah metode penelitian deskriptif dengan teknik studi korelasional (correlation study), di mana teknik korelasi ini bertujuan untuk mengetahui ada tidaknya hubungan antara variabel $\mathrm{X}$ dengan variabel $\mathrm{Y}$ dan apabila ada, seberapa erat dan seberapa berartinya hubungan tersebut (Arikunto, 1997). Teknik korelasi ini menghasilkan koefisien korelasi yang menunjukkan ada atau tidaknya korelasi linear antara dua variabel dalam penelitian. Linear disini berarti bahwa setiap kenaikan satu satuan pada variable $X$ maka diikuti dengan kenaikan satu satuan pada variabel Y. Seperti diungkapkan Sudjana (1997) bahwa koefisien korelasi menunjukkan apakah cukup beralasan bagi kita untuk menyatakan ada atau tidak adanya hubungan linear antara variabel-variabel $\mathrm{X}$ dan $\mathrm{Y}$. 


\section{Hasil Penelitian dan Pembahasan}

Tujuan penelitian ini untuk mengetahui bagaimana hubungan antara forgiveness dan post traumatic growth pada wanita dewasa awal yang mengalami kekerasan dalam pacaran di Kota Bandung. Post traumatic growth merupakan suatu perubahan positif seseorang menuju level yang lebih tinggi setelah mengalami peristiwa traumatis dan juga perjuangan yang dialami individu dalam menerima kenyataan baru setelah trauma (Tadeschi dan Calhoun, 2006). Sementara forgiveness adalah serangkaian perubahan motivasi seseorang untuk menurunkan motivasi membalas dendam, motivasi untuk menjauhkan diri atau menghindari orang yang menyakiti serta meningkatnya motivasi untuk berbuat baik dan berdamai kepada orang yang sudah melakukan tindakan yang menyakitkan (McCullough, Worthington \& Rachal ,1997).

Hasil penelitian yang dilakukan peneliti, dengan total responden sebanyak 96 orang, didapatkan bahwa didapatkan nilai korelasi antara forgiveness dan post traumatic growth 0,331 dengan nilai signifikansi sebesar 0,001. Hal ini dapat disimpulkan bahwa terdapat hubungan yang signifikan antara Forgiveness dan post traumatic growth karena nilai signifikansi yang didapatkan sebesar $0,000<0,05$. Sedangkan nilai korelasi yang cukup signifikan yaitu sebesar 0,331 yang mengindikasikan bahwa terdapat hubungan yang positif antara Forgiveness dan post traumatic growth, artinya bahwa semakin tinggi Forgiveness maka post traumatic growth akan semakin tinggi, begitu pula sebaliknya bahwa semakin rendah Forgiveness maka post traumatic growth akan semakin rendah. Hipotesis dalam penelitian ini diterima, dimana terdapat hubungan yang signifikan antara Forgiveness dan post traumatic growth.

Hal ini sejalan dengan penelitian yang dilakukan oleh Gilo, Feigelman \& Belz (2020) didapatkan bahwa forgiveness berkontribusi positif terhadap PTG secara langsung melalui proses interpersonal dan kognitif. Temuan ini menyoroti nilai tindakan yang mempromosikan pengampunan diri, kasih sayang, dan penerimaan dalam intervensi psikologis. Dalam penelitian ini menyoroti bahwa korban yang memaafkan merasa lebih bahagia, lebih tidak merasa khawatir, dan lebih positif dari pada orang yang tidak pemaaf. Selain itu, hasil dari penelitian ini juga sejalan dengan apa yang dikemukakan oleh Freedmen \& Enright (1996), bahwa pemaafan merupakan terapi yang efektif dalam beberapa kasus klinis, seperti pelecehan seksual, kekerasan dalam keluarga, kekerasan dalam rumah tangga dan beberapa jenis kekerasan lainnya.

Hasil penelitian menunjukkan sebanyak $78,1 \%$ responden berada dalam kategori post traumatic growth sedang yang artinya sudah terbentuknya kemampuan untuk bangkit dari keterpurukan dan mengalami perubahan positif berdasarkan proses belajar individu dari permasalahan yang dihadapi (dalam hal ini, trauma pasca kekerasan dalam pacaran. Para subjek dalam menunjukkan kemampuan untuk dapat memiliki hubungan dengan orang lain yang semakin terbuka dan dekat dengan orang-orang disekitarnya. Adanya peningkatan keyakinan dan spiritual dalam diri subjek menjadi aspek yang mendorong subjek untuk memperbaiki diri menjadi pribadi yang lebih baik lagi dan mendekatkan diri pada Tuhan. Selain itu, penghargaan hidup subjek dalam peningkatan aspek positif dalam hidup memicu subjek untuk menjadikan pengalaman traumatik tersebut sebagai pelajaran. Hal ini disebabkan oleh perkembangan kognitif dewasa awal pada tahap pemikiran pascaformal yaitu jenis berpikir matang yang bergantung pada pengalaman subjektif dan intuisi serta logika, berguna dalam menghadapi ambiguitas, ketidakpastian, inkonsistensi, kontradiksi, ketidaksempurnaan, dan kompromi (Piaget, dalam Papilia, Olds, dan Feldman, 2009).

Selanjutnya sebanyak $78,1 \%$ responden dalam penelitian ini berada dalam kategori forgiveness sedang yang berarti bahwa subjek menunjukkan terbentuknya perubahan motivasi untuk menurunkan motivasi membalas dendam, motivasi untuk menjauhkan diri atau menghindari orang yang menyakiti serta meningkatnya motivasi untuk berbuat baik dan berdamai kepada orang yang sudah melakukan tindakan yang menyakitkan (McCullough, Worthington \& Rachal, 1997). Hal ini juga menunjukkan bahwa para subjek yang mengalami kekerasan dalam pacaran memiliki tingkat pemaafan yang lebih baik. Hal ini sejalan dengan penelitian yang dilakukan Tsang \& Stanfort (2002) ditemukan bahwa wanita yang menjadi korban kekerasan cenderung lebih mudah memaafkan karena mereka memiliki rasa empati 
dan religiusitas yang tinggi, memiliki rasa cinta dan komitmen moral yang tinggi.

Diantara dua aspek Forgiveness, aspek Avoidance Motivation memiliki korelasi yang lebih tinggi dalam membentuk Forgiveness yaitu hasil analisis korelasi didapatkan korelasi antara Aspek Avoidance Motivation dan Forgiveness sebesar 0,902. Hal ini berarti bahwa terjadi penurunan motivasi pada korban untuk menghindari kontak pribadi ataupun kontak psikologis dengan pelaku. Hal tersebut menunjukan bahwa mayoritas responden dapat melalui tahap forgiveness yang karena para rospenden tersebut melakukan penurunan motivasi untuk menghindar dalam diri individu yang akhirnya membentuk pula proses pemaafan yang mereka capai (McCullough, Worthington \& Rachal ,1997). Selanjutnya berdasarkan hasil analisis korelasi didapatkan korelasi antara Aspek Avoidance Motivation dan post traumatic growth sebesar 0,234 sedangkan korelasi antara Aspek Revenge Motivation dan post traumatic growth sebesar 0,354. Pada analisis ini dapat disimpulkan bahwa diantara dua aspek Forgiveness, aspek Revenge Motivation memiliki korelasi yang lebih tinggi dalam membentuk post traumatic growth.

Dari hasil Analisa korelasi yang menunjukan dimana dua aspek Forgiveness, aspek Revenge Motivation memiliki korelasi yang lebih tinggi dalam membentuk post traumatic growth. Hal ini menjadi sebuah temuan yang sejalan dengan teori yang dikemukakan oleh Murray (2007), dimana korban kekerasan dalam pacarana cenderung mudah untuk terjebak dalam vicious cycle yaitu lingkaran berulang yang dalam fase bulan madun atau honeymoon phase-nya korban cenderung rentan untuk terbuai kembali untuk menuruti keinginan pelaku kekerasan. Oleh karena itu dalam temuan ini, mayoritas korban yang sudah mengalami pertumbuhan pasca trauma cenderung memiliki avoidance motivation yang rendah dimana korban cenderung untuk menghindar dan tidak memiliki motivasi untuk kembali menjalin hubungan interpersonal dengan pelaku.

Pada variable post traumatic growth diantara lima aspek post traumatic growth, aspek Spiritual Development memiliki korelasi yang lebih tinggi dalam membentuk post traumatic growth pada responden yang mengalami kekerasan dalam pacarana. Hal ini menunjukan bahwa mayoritas responden dapat mencapai pertumbuhan pasca trauma karena adanya peningkatan aspek perkembangan spiritual. Hal ini sesuai dengan yang diungkapkan Tadechi dan Calhoun (2006) dalam teorinya dijelaskan bahwa PTG hampir selalu berkaitan dengan aspek spiritual dimana dalam konteks mengacu pada rasa syukur terhadap Sang Pencipta. Sedangkan berdasarkan hasil analisis korelasi didapatkan korelasi antara Aspek post traumatic growth dan Forgiveness didapatkan bahwa Korelasi yang paling signifikan adalah antara New Possibilities dan Forgiveness memiliki nilai 0,309 yang berarti new possibilities mempunyai andil yang cukup besar dalam pemaafan karena ketika individu dihadapkan dengan resiko hidup negatif maka individu akan mencari kemungkinan-kemungkinan baru untuk dicari jalan keluar yang salah satunya dengan melakukan pemaafan.

Berdasarkan data yang didapat mengenai tabulasi slang antara forgiveness dan usia, menunjukan bahwa mayoritas responden sebanyak $78.1 \%$ di tingkat forgiveness yang tinggi, yang berarti $78.1 \%$ responden cukup baik dalam memaafkan atas tindak kekerasan dalam pacarannya. Dari data diatas mayoritas responden yang memiliki tingkat forgiveness tinggi adalah wanita berusia 20 tahun yaitu sebanyak 19,8\%, kemudian want berusia 22 tahun sebanyak 14,6\% dan want berusia 21 tahun yaitu sebanyak 12,5\%. Hal ini menunjukan bahwa ada pengaruh usia terhadap tinkgkat pemaafan wanita, asumsi ini selaras dengan penelitian Steiner, Allemand, dan McCullough (2011) bahwa pemaafan dapat bervariasi di berbagai usia. Rata-rata anak-anak yang berusia masih muda maupun remaja lebih sedikit berkeinginan untuk memberikan maaf pada orang lain. Sedangkan, individu dengan usia lebih dewasa memiliki keinginan untuk memaafkan kesalahan orang lain.

Selanjutnya berdasarkan tabulasi silang antara lama terlepas dari hubungan dan forgiveness didapatkan bah mayoritas responden yaitu sebanyak 38,5\% responden yang telah telepas dari hubungan Penuh kekerasan selama 9-12 bulan memiliki tingkat forgiveness yang tinggi, selanjutnya $15,6 \%$ responden yang Sudan terlepas lebih dari 18 bulan memiliki tingkat forgiveness yang tinggi dan 9,4\% responden yang sudah terlepas selama 12-15 bulan memiliki tingkat forgiveness yang tinggi. Hal ini sejalan dengan penelitian yang dilakukan oleh 
Alentina (2017) yang mengungkapkan bahwa subjek membutuhkan waktu untuk dapat mencapai tingkat pemaafan.

\section{Kesimpulan}

Berdasarkan pembahasan dalam penelitian ini, peneliti menyimpulkan beberapa hasil penelitian sebagai berikut:

1. Sebanyak $78.1 \%$ resonden termasuk Forgiveness Tinggi, yang berarti perempuan dewasa usia awal dengan tingkat forgiveness yang baik atas tindak kekerasan dalam berpacaran.

2. Sebanyak $11,5 \%$ dengan tingkat PTG yang tinggi, yang berarti perempuan korban kekerasan dalam berpacaran pada usia dewasa awal dapat bangkit dengan cepat dari traumatis yang di alami saat mengalami kekerasan dalam berpacaran. Sebanyak 78,1\% dengan tingkat PTG yang sedang, yang berarti perempuan korban kekerasan dalam berpacaran pada usia dewasa awal cenderung sedikit sulit untuk bangkit dan membutuhkan waktu untuk bangkit dari traumatis yang di alami setelah mengalami kekerasan dalam berpacaran.

3. Terdapat hubungan positif yang signifikan antara forgiveness dan post traumatic growth perempuan dewasa awal korban kekerasan dalam pacaran di Kota Bandung. Semakin tinggi semakin tinggi Forgiveness maka post traumatic growth akan tinggi pula, begitu juga sebaliknya semakin rendah forgiveness remaja maka semakin rendah pula post traumatic growth-nya.

Berdasarkan temuan-temuan bahwa KDP yang paling banyak terjadi pada perempuan berumur 20 tahun dengan lamanya berpacaran selama 15-18 bulan cenderung memerlukan waktu untuk dapat memaafkan dan mencapai tingkat forgiveness yang tinggi. Oleh karena itu peneliti menyarankan untuk demikian peneliti menyarankan untuk dilakukan edukasi dan memberikan pemahaman kepada generasi muda khususnya kaum perempuan berusia dewasa awal tentang adanya resiko terutama efek psikologis. Edukasi ini dapat berupa langkah preventif, promotif dan kuratif.

\section{Acknowledge}

Peneliti mengucapkan terima kasih kepada Ibu Eni Nuraeni Nugrahawati, Dra., M.Pd., Psikolog dan Ibu Dinda Dwarawati, S.Psi., M.Psi. selaku dosen pembimbing yang telah memberi arahan, bimbingan, juga meluangkan waktu selama penelitian ini berlangsung. Peneliti juga berterimakasih kepada seluruh responden yang telah bersedia untuk berpartisipasi dalam penelitian ini sehingga akhirnya penelitian ini dapat terwujud.

\section{Daftar Pustaka}

[1] Ariestina, D. (2009). Kekerasan Dalam Pacaran Pada Siswi Sma di Jakarta. Kesmas: Jurnal Kesehatan Masyarakat Nasional (National Public Health Journal), 3(4), 161-170.

[2]Bird, E., \& Melville, K. (1994). Families and intimate relationships. New York: Mc. Graw Hill, Inc.

[3]Florsheim, P. (2003). Adolescent Romantic Relations and Sexual Behavior. New Jersey: Lawrence Erlbaum.

[4]Gilo, T., Feigelman, W., \& Levi-Belz, Y. (2020). orgive but not forget: From selfforgiveness to posttraumatic growth among suicide-loss survivors. Death Studies. Advance online publication. https://doi.org/10.1080/07481187.2020.1864064.

[5]Hafnidar, H., Lin, H., \& Chang, L. (2012). Forgiveness as a Mediator for the Relationship between Spirituality and Posttraumatic Growth in Aceh Conflict Victims, Indonesia. International Journal of Social Science and Humanity DOI:10.7763/IJSSH.2012.V2.102.

[6]Herusansono, Winarto. (2012). St... Kekerasan dalam Pacaran Meningkat! Semarang: Kompas.com .

[7] Joseph, S., \& Liney, P. (2012). Trauma, Recovery and Growth. New Jersey: John Wiley and Sons, Inc. 
[8] Komisi Nasional Anti Kekerasan terhadap Perempuan (Komnas Perempuan) . (2020). Siaran Pers Komnas Perempuan Catatan Tahunan 2016. Retrieved Desember 18, 2020, from www.komnasperempuan.go.id: https://www.komnasperempuan.go.id/read-news-siaranpers-komnas-perempuan-catatantahunan-catahu-2016

[9] Mason, J. (2013). Posttraumatic growth in female sexual assault survivors. Knoxville: The University of Tennessee.

[10] McCullough, Michael E. , Fincham, Frank D. \& Jo-Ann Tsang. (2003). Forgiveness, Forbearance, and Time: The Temporal Unfolding of Transgression-Related Interpersonal Rusyidi, B., \& Hidayat, E. N. (2020). Kekerasan dalam pacaran: Faktor risiko dan pelindung serta implikasinya terhadap upaya pencegahan. Sosio Informa, 6(2), 152-169. https://doi.org/10.33007/inf.v6i2.2208

[11] Ramos \& Leal. 2013. Posttraumatic Growth in The Aftermath of Trauma : A Literature Review About Related Factors and Application Contexts. Psychology Community \& Health. 2 (1), 43-54

[12] Santrock, J. W. (2012). Child Development (Perkembangan Anak ,Edisi 11 Jilid 2, Penerjemah: Rachmawati dan Kuswanti). Jakarta: Erlangga .

[13] Santrock, J. (2007). Remaja. Jakarta: Erlangga.

[14] Sembiring, G. (2018). Kekerasan dalam pacaran (kdp) pada remaja putri usia 15-18 tahun di sma muhammadiyah 4 Kota Bengkulu. Jurnal Media Kesehatan, 7(2), 113118. https://doi.org/10.33088/jmk.v7i2.233

[15] Motivations. Journal of Personality and Social Psychology

[16] Sugiyono. (2017). Metode Penelitian Kuantitatif, Kualitatif, dan R\&D. Bandung: Alfabeta, CV. 